\section{Saints and Martyrs}

IN a lecture of this title recently delivered at the London Hospital and published in the Lancet of November 7, Dr. Donald Hunter, physician to the Hospital, remarks that the world to-day is too busy applauding successful military commanders, popular orators and authors to recognize that all its material advance has been achieved by men of science. $\mathrm{He}$ quoted numerous instances of scientific and medical men who were distinguished by having met dangers and often death for the sake of their work. In the first place he showed how our knowledge of toxic gases owed much to the self-sacrifice of pioneer workers, as in the cases of Gehlen, a Munich chemist, and Dr. K. C. Shierbeck, of Copenhagen, whose deaths in 1815 and 1920 respectively were due to arseniuretted hydrogen. In like manner, nitrous oxide proved fatal to Dr. S. R. Wilson in 1927, and hydrofluoric acid to Louyet and Nickles in 1869. In addition to numerous deaths among doctors and nurses due to attending patients suffering from acute infectious diseases, many laboratory workers have lost their lives in the investigation of certain dangerous tropical diseases, especially yellow fever, following experimental mosquito bites, as in the case of Lazear in 1900 and Walter Myers in 1901, pneumonic plague (T. C. Parkinson, 1909), verrugas (D. A. Carrion) and kala azar (W. R. Pirie). Numerous injuries and deaths from X-rays after many years of suffering occurred in radiologists before efficient means of protection were discovered, while it is not yet practicable to protect completely those who handle radioactive substances.

\section{Work of the Meteorological Office}

THE annual report of the director of the Meteorological Office for the year ending March 31, 1936 (H.M. Stationery Office, 1s. net), describes the work done by that Office in its eighty-first year. Military operations are now so dependent upon the help of organized meteorology that an atmosphere of suspicion, merely, between European nations causes repercussions that affect the development of meteorology. In the year under review the Royal Air Force expanded: the Meteorological Office did likewise. Early in October 1935, an Overseas Division was formed to deal with Empire air routes, including the projected trans-Atlantic routes and the Empire air mail scheme. In addition, new stations were opened during the year at Aden, Khartoum and Gibraltar. As additional trained staff could not at once be produced to meet the emergency, the staff at headquarters and some out-stations in Great Britain had to be drawn on for service abroad, in spite of the general increase of work at home, which was augmented by the decision to carry out the scheme of grading and pay recommended by the Committee on the Staffs of Government Scientific Establishments presided over by Sir Harold Carpenter. These activities were not, however, allowed to prevent proper attention being given to two important conferences, the Empire Conference of August 1935 held in London and the International
Conference of the following month in Warsaw. The Empire Conference met for discussion of research; the subjects for discussion were set out in sixty-eight memoranda. The International Conference was a gathering of directors of meteorological services, which among other achievements arrived at a uniform system of construction of synoptic weather maps-a valuable aid to international co-operation. The year's changes included also the setting up of an Overseas Division and the introduction in the official library on January 1, 1936, of a revised classification of meteorological literature based on that employed by the International Institute for. Documentation.

\section{Overhead Line Insulators}

IN a paper read to the Students' Section of the Institution of Electrical Engineers on November 30, Mr. C. H. W. Clark discussed the design, manufacture and testing of overhead line insulators. It is generally considered that 500,000 volts is the most economical pressure at which to transmit large quantities of electrical energy over long distances. The best material for insulating these lines has been found to be porcelain, as its insulating qualities remain practically the same when exposed to all weather conditions. It has low tensile strength but considerable compressive strength, and so most types of insulator are designed to utilize the porcelain in compression. Electrical failure follows a puncture through the porcelain or by 'flash-over' round its surface, which produces an arc short-circuiting the line. As puncture destroys the insulator, it is more serious than flash-over. Insulators are designed with a puncture voltage of about twelve times and a flash-over voltage of about six times the working voltage. Failures occurring in practice are usually due to lightning or to deposits of soot or sea salt on the insulator surface. Lightning affects the design of the transmission line rather than that of the insulators. Often no permanent damage is done by lightning flash-over. The problem of deposits on the surface of the insulators is a serious one and has not yet been completely solved, although many sugges. tions have been made for improving the standard types. For use near the sea, anti-deposit insulators have long, recessed, protected surfaces. For industrial areas, types with open exposed surfaces which can be cleaned by wind and rain have proved the best. For testing purposes, a percentage of the finished insulators are selected at random and tested for flash-over voltage both dry and in rain (produced artificially by a watering pot), impulse flashover voltage, mechanical strength and electrical puncture.

\section{Activities of the Imperial Agricultural Bureaux}

THE seventh annual report (1935-36) of the Executive Council of the Imperial Agricultural Bureaux has now been published (London: H.M. Stationery Office, 5s.). In view of the British Commonwealth Scientific Conference held in London this September, the volume is somewhat fuller than 
usual. Particular interest will perhaps be found in the individual reports of the several institutes and bureaux, where abundant illustration is afforded of the value now attached to them by the number and diversity of the inquiries sent from all parts of the Empire, quite apart from their regular work of preparing and distributing abstract journals. Research workers in South Africa, Queensland, Sierra Leone, Cyprus, Mauritius, Victoria, India, northern England and the Gold Coast have asked for and obtained assistance from the Mycological Institute in the identification of fungi. At the Entomological Institute, insects from every country in the Empire have been received for identification. Other bureaux have assisted in obtaining material for plant breeding work, in supplying seeds, in arranging for the analysis of foodstuffs ; whilst the laboratory attached to the Imperial Institute of Entomology collected and sent to Canada nearly three million parasites to aid in controlling the insect pests which were attacking the forests in Quebec and the Maritime Provinces. In fact, the report marks for the seventh year the success of an Imperial service, organized on a cooperative basis and directly controlled by representatives of all parts of the Commonwealth.

\section{Rock Gardening}

THE art of growing plants among rocks disposed artistically is, perhaps, the highest form of gardening. It calls forth skill of an exceptional order, and provides a medium for expression of the highest sense of art. The Royal Horticultural Society and the Alpine Garden Society are therefore to be congratulated upon their very successful joint organization of a conference on rock garden matters, and an exhibition of tasteful grouping of alpine plants. The deliberations of this Conference, which took place at the Greycoat Street Hall on May 5-7, 1936, have now been published in book form by the Royal Horticultural Society ("Rock Gardens and Rock Plants." London: from the Office of the Society, Vincent Square, S.W.1, pp. 171, 6s. net, 1936). Mr. F. J. Chittenden has edited this report of proceedings. Practical considerations were well to the fore. The utilization of natural slopes and of flat sites, the cultivation of difficult alpine plants, methods of propagation, the use of an alpine house, and other problems, were discussed. The history of rock gardens was outlined, and a very pleasing international atmosphere was introduced by the speakers who described rock gardening in South Africa (Miss Stanford), in Quebec (Mr. Cleveland Morgan) and in Southern California (Mr. W. Hertrich). The impression gained from the volume is that the artistic side of rock gardening could scarcely be improved, and that present-day practice is enlightened and highly skilled. There are abundant indications, however, in the papers and in the energetic and constructive discussion which followed them, that there is a field where a sympathetic man of science, working upon rock-garden problems, might furnish great contributions to practice, and satisfy many botanical questions which must at present be left unanswered.

\section{Forestry in British Honduras}

THE report of the Forest Trust of British Honduras to the end of December 1934 (Belsize : Govt. Printer, 1935) shows some progress in forestry work after the severe experiences following the 1931 financial crisis. From the Colonial Development Fund grants were made towards forest development in the Colony. The chief of these grants was to provide the staff to undertake a forest resources survey of the country, provided that the local Government contributed towards the cost and that the officer seconded for the work was replaced on the executive staff by an additional officer. The step so taken furnishes evidence of a broad vision on the part of the officials forming the Forest Trust. The term 'research work' accorded to what is mainly ordinary stock mapping of a forestthe work, or part of it, of the trained forest officer-is rather out of place, if not misleading. The staff of the Department, consisting of three gazetted officers, is still too small to make any considerable advance in executive forestry work a possibility. It is not therefore surprising to find in the Report such remarks as "No new reserves have been created"; "No new demarcation work was undertaken"; and, in spite of the magnificent start made in the early years of this young Department, that "No sylvicultural work has been done since the completion of the mahogany improvements in 1931". The end of the year 1934, which appears very distant at the present day, seemed to show an upward tendency in a timber trade revival. It was estimated by the Trust that the export of mahogany, that magnificent forest product of the British Honduras forests, would not exceed five or six million board feet per annum in the immediate future, and that a large proportion of that export would be in lumber form.

\section{Exhibition of Microscopes}

Messrs. W. Watson and Sons, Litd., heid their fourth exhibition of microscopes at the Central Hall, Westminster, on December 7-11, when the manifold uses of the microscope were practically illustrated, and many different types of instrument were on view. Members of the Quekett Microscopical Club were helpful in explaining points of interest to the scientific microscopist and instilling enthusiasm for microscopy in the amateur. A large number of different microscopes, from the comparatively simple student's microscope to the more intricate type used for research purposes, was on view. Other apparatus being demonstrated included photomicrographic and other cameras, dyes and stains, dissecting instruments, micro-projectors, telescopes, and other optical instruments. Messrs. Chance Bros. supplied an exhibition of glass in various stages from the rough mass to the finished optical lens. Messrs. Kodak also had an exhibition, as also had Polarisers, Ltd. A catalogue of the exhibition forms a useful guide to scientific workers in the many branches of science in which the microscope is indispensable and also to the amateur microscopist. The catalogue can be obtained from Messrs. W. Watson and Sons, Ltd., 313 High Holborn, London, W.C.1. 